\title{
The Relationship Between Frailty and Treatment Compliance in Diabetic and Geriatric Patients Using Insulin
}

\author{
Diabetes Mellitus Tanılı Insülin Kullanan Geriatrik Hastalarda Tedaviye Uyum ve Kırılganlık \\ Arasındaki Ilişki
}

\author{
(D) Imantay SHAUYET ${ }^{1}$, (D) Sema BASAT ${ }^{1}$, (D) Gamze GEYIK YÜNOĞLU1 ${ }^{1}$, (D) Rıdvan SIVRITEPE², (D) Selda ÇAKIN ÜNNÜ1, \\ (D) Mustafa Behçet DEMIRBAŞ ${ }^{1}$, (D) Mevlüt KIYAK${ }^{1}$, (D) Okcan BASAT ${ }^{3}$ \\ ${ }^{1}$ University of Health Sciences Turkey, Ümraniye Training and Research Hospital, Clinic of Internal Diseases, Istanbul, Turkey \\ 2Beykoz State Hospital, Clinic of Internal Diseases, istanbul, Turkey \\ 3 University of Health Sciences Turkey, Gaziosmanpaşa Taksim Training and Research Hospital, Clinic of Family Medicine, istanbul, Turkey
}

ÖZ

Aim: Understanding and detecting frailty makes convenience to healthcare providers for deciding on appropriate therapy and follow-up strategy. In this study, we tried to determine the relationship between compliance to therapy, hypoglycemia and frailty in the elderly diabetic patients under insulin therapy.

Materials and Methods: One hundred sixty-seven patients diagnosed with diabetes mellitus and under insulin therapy were recruited for the study. Criteria of frailty according to the Cardiovascular Health Study (CHS) were used to determine frailty. According to CHS, patients fulfilling three or more criteria out of five were regarded as frail elderly. Hypoglycemia rates and compliance to treatment were compared between the groups.

Results: $44.3 \%$ of our patients were regarded as frail elderly and the rate of hypoglycemia was higher in this group. A dignificant relationship between subgroups of frailty and insulin was detected. Frailty rate was 28.6\% in the basal insulin therapy group, 37.1\% in the basal-bolus therapy group and $40 \%$ in the premixed insulin group. In the frail elderly group, the rate of moderate hypoglycemia was significantly higher than in the non-frail group (40.2\% vs 20\%). Severe hypoglycemic episodes were observed more frequently in the frail elderly group than in the non-frail group (24.6\% vs $12.7 \%)$.

Conclusion: Frailty increases the risk of moderate and severe hypoglycemia. Before planning and starting insulin therapy, frailty must be detected and taken into consideration.

Keywords: Diabetes mellitus, frailty, hypoglycemia, elderly

\section{ABSTRACT}

Amaç: Geriatrik hastalarda kırılganlığı anlamak ve tespit etmek, hastaları takip etmede ve uygulanacak tedavi seçiminde sağlık ekibine büyük kolaylık sağlayacaktır. Biz bu çalışmada diabetes mellitus tanılı insülin kullanan geriatrik hastalarda tedaviye uyum, hipoglisemi ve frailite arasındaki ilişkiyi belirlemeyi amaçladık.

Gereç ve Yöntem: Çalışmamıza diabetes mellitus tanıı insülin tedavisi kullanan 65 yaş ve üstü toplam 167 hasta alındı. Frailite değerlendirmesi için Kardiyovasküler Sağlık Çalışması'na göre frailite kriterleri kullanıldı. Buna göre 5 özellikten 3 ve daha fazlasını taşıyan hastalar kırılgan yaşlı olarak kabul edildi. Kırılgan hastalarda ise Kanada Sağlık ve Yaşıııı Çalışması'nda önerilen kırılganlık kriterleri ve puanlama kullanıldı.

Bulgular: Hastaların \%44,3'ünde frailite olduğunu ve kırılgan olan hastaların hipoglisemi oranının daha yüksek olduğunu saptadık. Çalışmamızda kırılgan grupta daha fazla hipoglisemi olduğu gösterildi. Kırılganlık ile insülin grupları arasında anlamlı farklılık bulundu. Bazal insülin kullanan grupta frailite oranı \%28,6, bazal bolus grubunda frailite oranı \%37,1, karışım insülin kullanan grupta ise frailite oranı \%40 ile daha yüksek saptandı. Orta derece hipoglisemi frailitesi olanlarda olmayanlara göre 2 kat daha yüksekti (\%40,2-20). Ağır hipoglisemi kırılgan olmayan grupta \%12,7 iken, kırılgan olan grupta \%24,6 oranında saptandı.

Address for Correspondence: Rıdvan SIVRiTEPE MD, İstanbul Medipol University Faculty of Medicine, Pendik Hospital, Clinic of Internal Medicine, İstanbul, Turkey Phone: +90 5452605957 E-mail: dr.ridvansivritepe@gmail.com ORCID ID: orcid.org/0000-0003-0547-1883

Received: 11.02.2021 Accepted: 02.04.2021

๑ Copyright 2021 by the Tekirdağ Namık Kemal University Faculty of Medicine / Namık Kemal Medical Journal published by Galenos Publishing House. 
Sonuç: Frailite varlığının orta ve ağır hipoglisemi riskini belirgin şekilde artırdığını ve insülin tedavisi planlanıyorsa kırılganlığın tespit edilmesi ve tedavi düzenlenirken bu durumun mutlaka göz önüne alınması gerektiğini söyleyebiliriz.

Anahtar Kelimeler: Diabetes mellitus, kırılganlık, hipoglisemi, yaşlılık

\section{INTRODUCTION}

The population of our country has been reported as 83 million 154 thousand as of 2020. Looking at the population pyramid, it has a young population. However, as in the whole world, the elderly population is increasing rapidly in our country'. According to the Turkish Statistical Institute 2020 data, the elderly population constitutes $9.1 \%$ of the country². The World Health Organization states that the number of geriatric people in the world will reach 1.2 billion by $2025^{3}$. Due to the increase in the geriatric population and the changing lifestyle, chronic diseases are increasing in our country. The increasing elderly population brings with it problems specific to the elderly. One of these problems is the concept of frailty. The American Medical Association used the word "frailty" to describe "the patient group that presents the most complex and challenging problems for healthcare professionals" ${ }^{4}$. While frailty is seen at a rate of $10-25 \%$ in people aged 65 and over, it increases to $30-45 \%$ in people aged 85 and over ${ }^{5}$. Understanding and knowing the frailty in the geriatric population will provide great convenience to the healthcare team in following up the patients and choosing the treatment to be applied. With this study, we wanted to address frailty and frailty criteria in the geriatric population, while addressing frailty in the diabetic elderly patient group, which is an important problem. Insulin therapy should be carefully planned, especially in the diabetic elderly. Therefore, correct classification of cases is important. Indices used in patient selection exclude the concept of frailty. In this study, we aimed to investigate the relationship between compliance to treatment and frailty (weakness, weight loss, slowness, decreased physical activity, decreased stamina and energy) in patients aged 65 and over using insulin and diagnosed with diabetes mellitus.

\section{MATERIALS AND METHODS}

Our study is an analytical cross-sectional study and was conducted with a total of 167 patients aged 65 years and older, who were diagnosed with diabetes mellitus and were using insulin therapy, who applied to Ümraniye Training and Research Hospital Internal Medicine outpatient clinics or were hospitalized for various complications and chronic diseases. Ethics committee approval was obtained from the of Ümraniye Training and Research Hospital Ethics Committee for the study (decision number: 56, date: 24.09.2014). An informed consent form was signed by all patients participating in the study. Geriatric patients aged 65 years and older with diabetes mellitus using insulin were included in the study. Patients with congenital disability and malignancy abd those who did not want to participate in the study were not included.

\section{Frailty Assessment}

For the assessment of frailty in the geriatric population, frailty criteria (fatigue, weight loss, slowness, decreased physical activity, decreased stamina and energy) according to the Cardiovascular Health Study (CHS) were used. According to the CHS criteria, patients with 3 or more of 5 characteristics were considered frail elderly. While scoring, frailty criteria and scoring recommended in the Canadian Health and Aging Study were used; classification was made as mild frailty (patients with 1 point), moderate frailty (patients with 2 points), and severe frailty (patients with 3 points).

\section{Metabolic Parameters}

Plasma glucose of all patients was measured by enzymatic test; HPLC method was used to measure glycosylated hemoglobin; total cholesterol, high-density lipoprotein cholesterol, calcium, phosphate and triglyceride concentration were measured by enzymatic colorimetric test; and creatinine was measured by the Jaffe' method [Hitachi 747 autoanalyzer (Mito, Ibaragi, Japan)]. Blood samples were taken from the patients between 08:00 and 10:00 on an empty stomach. Blood samples were collected into tubes with SST II, LH PST II and EDTA and analyzed simultaneously.

\section{Statistical Analysis}

IBM Statistical Package for the Social Sciences Statistics 22.0 IBM Software program was used for statistical analysis. While evaluating the study data, in addition to descriptive statistical methods (mean, standard deviation), the One-Way ANOVA test was used to compare the parameters with normal distribution between groups in the comparison of quantitative data, and the Tukey HSD test was used to determine the group that caused the difference. Chi-square test was used to compare qualitative data. Spearman correlation analysis was used to examine the relationships between parameters that did not conform to the normal distribution. Significance was evaluated at the $p<0.05$ level.

\section{RESULTS}

A total of 167 patients were evaluated. In the sample distribution, $92(55.1 \%)$ of the cases were female and 75 
(44.9\%) male. The mean age of the cases was detected as $71.83 \pm 6.11$ years. The majority of the participants were able to meet their bathroom, dressing and toilet needs. While fecal incontinence was present in $28.70 \%$ of the patients, it was absent in $71.30 \%$ of them. $79.60 \%$ of the participants could meet their food needs. The rate of those who could not meet their food needs was $19.80 \%$, the rate of those who did with support was $0.60 \%$. While hypoglycemia was present in $52.70 \%$ of the participants, it was absent in $47.30 \%$ of the participants. Of the patients participating in the study, 21.6\% had heart failure, $83.2 \%$ had hypertension, 15\% had cerebrovascular accident and dementia, and $17.4 \%$ had chronic renal failure. Of the patients using insulin, 41.9\% were using basal insulin, $37.1 \%$ were using basal+bolus insulin and $2 \%$ were using mixed insulin. The number of patients using oral antidiabetic (OAD) was approximately $17 \%$ less than those who did not. When all cases were evaluated, the frailty rate was found to be $44.3 \%$. The rate of participants without hypoglycemia was $47.3 \%$. The rate of those with severe hypoglycemia was $16.80 \%$. The proportion of participants with mild hypoglycemia was $8.40 \%$. The total hypoglycemia rate was found to be $52.7 \%$. In the analysis made between daily activities and frailty, a relationship was found between the form of activity and frailty in all activities.

When frailty was evaluated according to age groups, the frailty group was older than the non-frailty group. The comparison of frailty criteria and age in frail and non-frail groups is summarized in Table 1. Heart failure, cerebrovascular disease and dementia were detected more frequently in the frail patient group $(p<0.05)$ (Table 2$)$. While the rate of moderate hypoglycemia was $20 \%$ in non-frailty patients, this rate was $42.1 \%$ in frailty patients and while the rate of severe hypoglycemia was $12.7 \%$ in patients without frailty, this rate was found as $24.6 \%$ in patients with frailty. Moderate and severe hypoglycemia was 2 times higher in the frail group (Table 3). In the evaluation we made between the frailty groups and the insulin groups, there was $28.6 \%$ frailty in the basal insulin group, 37.1\% in the basal-bolus group and $40 \%$ in the mixed insulin group. The frailty rate was found to be higher in patients using basal-bolus and mixed regimen insulin (Table 4). A significant correlation was found between the HbA1c groups and the insulin groups. While the rate of patients with $\mathrm{HbA} 1 \mathrm{c}$ level above 10 was $18.6 \%$ in the group using basal insulin, it was $35.5 \%$ in the group using basal-bolus insulin and $14.3 \%$ in the group using mixed insulin. In the correlation analysis between frailty and age groups, hypoglycemia groups and HbA1c groups; a positive significant correlation was found between frailty and age groups and hypoglycemia.

\section{DISCUSSION}

In this study, we found that the rate of frailty was $44.3 \%$ in patients over 65 years of age using insulin, and the rate of

\begin{tabular}{|c|c|c|c|c|c|c|}
\hline & & \multicolumn{2}{|c|}{ Frail } & \multicolumn{2}{|c|}{ Non-frail } & \multirow{2}{*}{ p } \\
\hline & & $n$ & $\%$ & $\mathbf{n}$ & $\%$ & \\
\hline \multirow{3}{*}{ Age group } & $60-70$ & 55 & $50.5 \%$ & 14 & $24.6 \%$ & \\
\hline & $70-80$ & 44 & $40.4 \%$ & 28 & $49.1 \%$ & \\
\hline & $>80$ & 10 & $9.2 \%$ & 15 & $26.3 \%$ & 0.01 \\
\hline \multirow{3}{*}{ Bathing } & None & 4 & $3.7 \%$ & 35 & $61.4 \%$ & \\
\hline & Yes & 105 & $96.3 \%$ & 3 & $5.3 \%$ & 0.01 \\
\hline & $\begin{array}{l}\text { With } \\
\text { support }\end{array}$ & 0 & $0.0 \%$ & 19 & $33.3 \%$ & \\
\hline \multirow{3}{*}{ Dressing } & None & 4 & $3.6 \%$ & 35 & $61.4 \%$ & \\
\hline & Yes & 106 & $96.4 \%$ & 10 & $17.5 \%$ & 0.01 \\
\hline & $\begin{array}{l}\text { With } \\
\text { support }\end{array}$ & 0 & $0.0 \%$ & 12 & $21.1 \%$ & \\
\hline \multirow{3}{*}{$\begin{array}{l}\text { Using the } \\
\text { toilet }\end{array}$} & None & 5 & $4.5 \%$ & 35 & $61.4 \%$ & \\
\hline & Yes & 105 & $95.5 \%$ & 6 & $10.5 \%$ & 0.01 \\
\hline & $\begin{array}{l}\text { With } \\
\text { support }\end{array}$ & 0 & $0.0 \%$ & 16 & $28.1 \%$ & \\
\hline \multirow{2}{*}{ Stool } & None & 101 & $91.8 \%$ & 18 & $31.6 \%$ & \\
\hline & Yes & 9 & $8.2 \%$ & 39 & $68.4 \%$ & 0.01 \\
\hline \multirow{3}{*}{ Food } & None & 4 & $3.6 \%$ & 29 & $50.9 \%$ & \\
\hline & Yes & 106 & $96.4 \%$ & 27 & $47.4 \%$ & 0.01 \\
\hline & $\begin{array}{l}\text { With } \\
\text { support }\end{array}$ & 0 & $0.0 \%$ & 1 & $1.8 \%$ & \\
\hline \multirow{2}{*}{ Incontinence } & None & 95 & $86.4 \%$ & 12 & $21.1 \%$ & \\
\hline & Yes & 15 & $13.6 \%$ & 45 & $78.9 \%$ & 0.01 \\
\hline
\end{tabular}

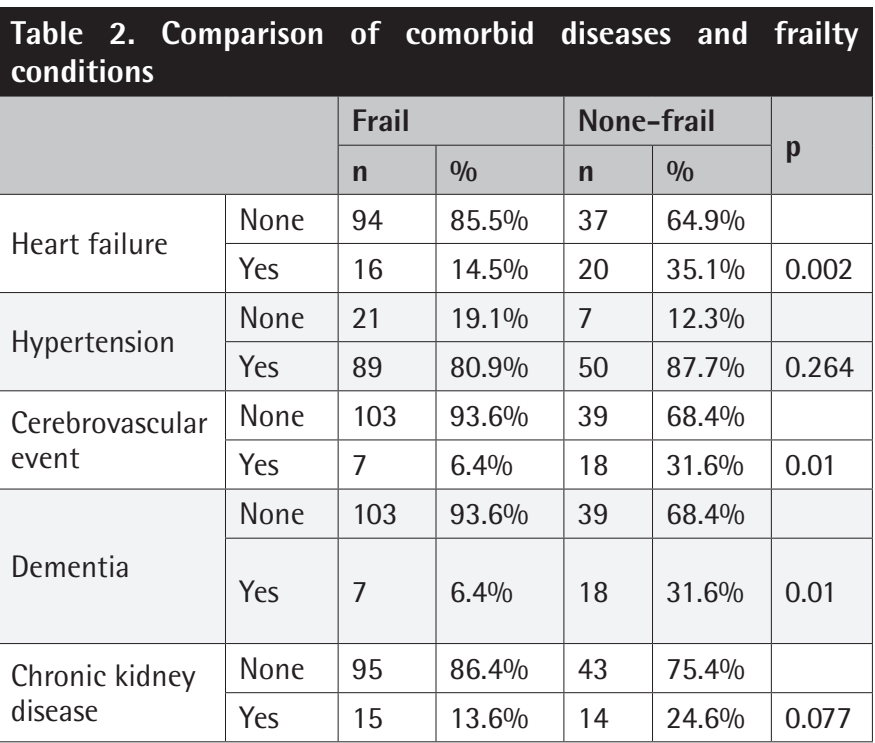

hypoglycemia was higher in patients with frailty compared to those without. We found a positive correlation between frailty and hypoglycemia. We showed that frailty increased as the degree of hypoglycemia increased. Life expectancy has been prolonged due to many important developments such as the success achieved in the treatment of diseases, the control of 
Table 3. Comparison of hypoglycemia and HbA1c levels and frailty status

\begin{tabular}{|c|c|c|c|c|c|c|}
\hline & \multicolumn{2}{|c|}{ Frail } & \multicolumn{2}{|c|}{ None-frail } & \multirow{2}{*}{ p } \\
\hline & & $\mathbf{n}$ & $\%$ & $\mathbf{n}$ & $\%$ & \\
\hline \multirow{4}{*}{ Hypoglycemia } & Severe & 14 & $12.7 \%$ & 14 & $24.6 \%$ & \\
\hline & Moderate & 22 & $20.0 \%$ & 24 & $42.1 \%$ & \\
\hline & Mild & 9 & $8.2 \%$ & 5 & $8.8 \%$ & \\
\hline & Normal & 65 & $59.1 \%$ & 14 & $24.6 \%$ & 0.01 \\
\hline \multirow{4}{*}{$\mathrm{HbA} 1 \mathrm{c}$} & $<6.5$ & 11 & $10.0 \%$ & 12 & $21.1 \%$ & \\
\hline & $6.5-8.5$ & 46 & $41.8 \%$ & 26 & $45.6 \%$ & \\
\hline & $8.5-10$ & 24 & $21.8 \%$ & 8 & $14.0 \%$ & \\
\hline & $>10$ & 29 & $26.4 \%$ & 11 & $19.3 \%$ & 0.143 \\
\hline
\end{tabular}

Table 4. Comparison of insulin regimes and frailty status

\begin{tabular}{|l|l|l|l|l|l|l|l|}
\hline & \multicolumn{3}{|l|}{ Basal } & \multicolumn{3}{l|}{ Basal-bolus } & \multicolumn{2}{l|}{ Mix } & \multirow{2}{*}{ p } \\
\cline { 2 - 8 } & $\mathbf{n}$ & $\%$ & $\mathbf{n}$ & $\%$ & $\mathbf{n}$ & $\%$ & \\
\hline Frail & 50 & $71.4 \%$ & 39 & $62.9 \%$ & 21 & $60.0 \%$ & \\
\hline None-frail & 20 & $28.6 \%$ & 23 & $37.1 \%$ & 14 & $40.0 \%$ & 0.01 \\
\hline
\end{tabular}

infectious diseases, and the improvement of living conditions, and accordingly, the elderly population is increasing rapidly in our country as in the world. Malnutrition, incontinence, inactivity, delirium, depression, falls, dementia, pain, gait disorders, osteoporosis, frailty and pressure sores are the most common problems in the elderly. Frail elderly syndrome has many different definitions. The definition with the greatest consensus is increased susceptibility to external stresses due to age-related physiological reserves, neuromuscular, metabolic, and immune system dysfunction. The frailty rate increases with age and reaches $30 \%$ over the age of 90 . Frail elderly people are the group that will benefit most from a comprehensive geriatric assessment. By identifying these elderly people and taking the necessary preventive and therapeutic measures in cooperation with their families, the morbidity and mortality rate can be reduced. In the literature, there are not enough studies on frailty in the diabetic elderly patient group. However, when the studies on frailty are examined, we see that these studies are carried out to find the most appropriate method for detecting frailty or to draw attention to frailty and to emphasize the inadequacies in this regard. Considering that studies on the life activities of the elderly are not sufficient in our country, in a study in which 400 patients aged 65 and over were included in a private hospital and their daily living activity indices were examined, the life activity performances of the patients between the ages of $65-70$ years $(52.5 \%), 70-75$ years (41.2\%), $75-80$ years $(43.8 \%)$ and $85-90$ years $(40 \%)$ were found to be "very good", only 50\% of patients aged 90-95 were "bad" and it was concluded that a multidisciplinary approach should be taken towards the general care of elderly patients. According to the results of this study, it has been shown that care and treatment approaches change as age increases ${ }^{6}$. In our study, the frail group was found to be older than the non-fragile group. While this rate was $24 \%$ for the 60-70 age group, it was 49\% for the $70-80$ age group. We have shown that frailty increases with age and decreased physical activity is also related to increased frailty, and care and treatment approaches for the elderly population change. In a study it is stated that in elderly patients with diabetes for several years and complications, tight glycemic control reduces the risk of microvascular events, but does not reduce macrovascular events or mortality, better glycemic control is associated with less disability and better organ function, but observation of severe hypoglycemia in advanced age is a risk factor for intensive treatment ${ }^{7-9}$. Again, in the same study, OAD basal-bolus therapy was compared and it was noted that frailty that increases with age is associated with decreased functions and increased mortality, and that elderly diabetic patients tend to be more frail?. In people with multiple comorbidities, the high functional variability and limited life expectancy suggest that the benefit of intensive therapy is minimal. The decision to recommend tighter or milder glycemic control is made according to the degree of weakness, and it is noted that the patients with moderate or more severe weakness should not have strict glycemic control because they have a reduced life expectancy, and that when glycemic control is tried to be better in these patients, maybe less pronounced hyperglycemia episodes are seen, but serious episodes of hypoglycemia are more frequent ${ }^{10}$. It is recommended that insulin treatment regimens in the elderly be individualized and determined by considering the safety of the patient. It has been concluded that pre-mixed insulin analogues can be used after meals and are associated with better control compared to basal insulins, but they cause more frequent hypoglycemia and more weight Ioss $^{11,12}$. Our study showed a positive relationship between frailty and age and hypoglycemia. While severe hypoglycemia was $39.3 \%$ in the $60-70$ age group, this rate was $50 \%$ in the 70-80 age group. No significant relationship was found between age groups and hypoglycemia, but a significant relationship was found in the relationship analysis between frailty groups and insulin groups. The frailty rate was $28.6 \%$ in the basal insulin group, $37.1 \%$ in the basal bolus group, and it was higher with $40 \%$ in the mixed insulin group. We believe that frailty should be taken into account when administering insulin therapy in the elderly patient group and treatment regimens should be adjusted accordingly. The least hypoglycemia was seen in the basal treatment group, and hypoglycemia rates increased significantly in both the mixed and basal bolus groups. In a study by Kim et al. ${ }^{13}$, it was stated that geriatric frailty is a syndrome and it affects treatment options. It was pointed out that the development and application of the statement-based frailty index in older adults should be determined and adjusted in pharmacoepidemiological studies, and that more research is needed. In a study by Sourial 
et al. ${ }^{14}$, it was aimed to evaluate 129 combinations of seven indicators of weakness (cognition, energy, mobility, mood, nutrition, physical activity, and strength) and to determine their predictive accuracy regarding age, gender, and number of chronic diseases. When 129 combinations of weakness indicators from the best model to the worst fit model are compared, it was found that the inclusion of multiple indicators generally improved performance and single markers gave the worst performance result. The results also suggest that frailty as a diagnostic tool, may play a more important role in the 80 and older age group. Although the "CHS model" and the "count model" are among the best models, it was concluded that both were not optimal. Compared to these two studies, our study used frailty criteria (fatigue, weight loss, slowness, decreased physical activity, decreased stamina and energy) according to the CHS to evaluate frailty and adherence to treatment in the geriatric population. In addition, hypoglycemia and other comorbid diseases were also questioned in the diabetic patient population over 65 years of age. While there was no significant relationship between frailty and hypertension and chronic kidney disease, a significant relationship was found between the presence of heart failure, cerebrovascular accident, dementia, hypoglycemia and frailty groups. The frailty rates were $35.1 \%$ in those with heart failure, $31.6 \%$ in those with cerebrovascular accident, and 31.6\% in those with dementia. Both moderate and severe hypoglycemia were observed 2 times more in the frail group. Based on this, we can say that the presence of frailty significantly increases the risk of moderate and severe hypoglycemia, and if insulin therapy is planned, frailty should be detected and this should be taken into account when arranging the treatment. In another study, it was stated that elderly diabetic patients are constantly at high risk of geriatric syndrome, and are at risk for functional impairment, depression, falls, urinary incontinence, malnutrition, and cognitive impairment. It was concluded that the treatment of diabetic patients with geriatric syndrome should focus on a strategy to prevent exacerbation of frailty ${ }^{15}$. In a published guideline, it is recommended that the treatment targets of blood glucose in elderly people with diabetes be individually determined according to age, life expectancy, patient preference, presence of geriatric syndrome, depression, pain, falling, incontinence, polypharmacy, and cognitive impairment ${ }^{16}$. In a study by Gregg et al. ${ }^{17}$, which included 6,588 residents aged 60 and over, it was reported that $32 \%$ of diabetic women and 15\% of men with diabetes did not have the capacity to walk a quarter of a mile, do housework or climb stairs, this rate for those without diabetes was detected as $14 \%$ for women and $8 \%$ in men. In a study by Amer et al. ${ }^{18}$ in which 104 elderly patients were included, similar to our study, it was seen that in physically frail cases the rate of associated chronic diseases, diabetes, ischemic heart diseases, hypertension, stroke, vision and hearing loss was significantly higher than others.

\section{Study Limitations}

Our study had some limitations. First, our study was a singlecenter cross-sectional analysis. Second, frailty was assessed at a single time point. Third, the presence of hypoglycemia was based on one-time measurement.

\section{CONCLUSION}

In conclusion, with this study, we wanted to draw attention to frailty in diabetic patients and to examine the effect of hypoglycemia on frailty. In all studies in the literature, it is not considered beneficial to try to keep blood glucose normoglycemic with intensive antidiabetic therapy in elderly diabetic patients ${ }^{19}$. Elderly diabetic patients have many risk factors such as a history of cardiovascular disease and other comorbid diseases. All these risk factors outweigh the benefits of intensive antiglycemic therapy in the elderly diabetic population. In the Action to Control Cardiovascular Risk in Diabetes study; it has been shown that giving intensive antiglycemic therapy and trying to reduce the $\mathrm{HbA} 1 \mathrm{c}$ target below $6 \%$ increase the risk of death from other causes or cardiovascular causes ${ }^{8}$. Similarly, it was found in the Veterans Affair Diabetes Trial study that excessive glycemic control failed to have benefit in cardiovascular endpoints ${ }^{20}$. In our study, we found that frailty increases the risk of hypoglycemia in the geriatric patient population using insulin. We also showed that other comorbid conditions, such as dementia and Alzheimer, are also associated with increased frailty. This revealed the necessity of considering comorbid conditions apart from activities of daily life when assessing frailty. We observed that fragility increases with increasing age. Considering that the majority of the diabetic patient population will be over the age of 65 in the near future, frailty syndrome will have even more importance. This shows that for elderly diabetic patients, these geriatric syndromes should be evaluated and the treatment should be arranged with this perspective. In addition to the agent to be chosen in the treatment of diabetic patients, attention should be paid to the issue of hypoglycemia. Ultimately, frailty will be beneficial for health improvement only if it is reversible or if adverse outcomes can be changed or at least improved. If the use of insulin is absolutely necessary in elderly individuals, choosing the regimen after considering the frailty will ensure compliance with the treatment and protect the individuals from complications.

\section{Acknowledgement}

We thank Ümraniye Training and Research Hospital for its support. 


\section{Ethics}

Ethics Committee Approval: The study were approved by the Ümraniye Training and Research Hospital Ethics Committee (decision number: 56, date: 24.09.2014).

Informed Consent: An informed consent form was signed by all patients participating in the study.

Peer-review: Externally peer-reviewed.

\section{Authorship Contributions}

Surgical and Medical Practices: I.S., S.B., S.Ç.Ü., Concept: I.S., R.S., M.B.D., Design: S.B., S.Ç.Ü., M.K., Data Collection or Processing: G.G.Y., R.S., M.B.D., Analysis or Interpretation: I.S., S.B., S.Ç.Ü., O.B., Literature Search: G.G.Y., R.S., M.B.D., Writing: I.S., S.B., S.Ç.Ü., M.K., O.B.

Conflict of Interest: No conflict of interest was declared by the authors.

Financial Disclosure: The authors declared that this study received no financial support.

\section{References}

1. Adrese Dayalı Nüfus Kayıt Sistemi Sonuçları. Türkiye İstatistik Kurumu Haber Bülteni, Sayı: 33705. Erişim tarihi: 04 Şubat 2020. Erişim adresi: https://tuikweb.tuik.gov.tr/PreHaberBultenleri.do?id=33705

2. İstatistiklerle Yaşlılar 2020. Türkiyei̇statistikKurumu Haber Bülteni. Sayı: 33712. Erişim tarihi: 18 Mart 2020. Erişim adresi: https://data.tuik.gov.tr/ Bulten/Index?p=Istatistiklerle-Yaslilar-2019-33712

3. World Health Organization. 10 Facts on age in gand the life course. World Health Organization, Geneva, Switzerland. Last accessed date: May 2017. Available from: http://www.who.int/features/factfiles/ageing/en/

4. American Medical Association white paper on elderly health. Report of the Council on Scientific Affairs. Arch Intern Med. 1990;150:2459-72.

5. Klein BE, Klein R, Knudtson MD, Lee KE. Frailty, morbidity and survival. Arch Gerontol Geriatr. 2005;41:141-9.

6. İnanır İ, Kayış A, Yılmaz K. The Activity of Daily Life in Elderly Patients. Akademik Geriatri Dergisi. 2013;5:64-72.
7. Meneilly GS, Aileen K, Daniel T. Diabetes in the Elderly. Can J Diabetes. 2013;37:184-90.

8. Gerstein HC, Miller ME, Byington RP, Goff DC Jr, Bigger JT, Buse JB, et al. Effects of intensive glucose lowering in type 2 diabetes. N Engl J Med. 2008;358:2545-59.

9. Wang CP, Hazuda HP. Better glycemic control is associated with maintenance of lower-extremity function over time in Mexican American and European American older adults with diabetes. Diabetes Care. 2011;34:268-73.

10. Lee SJ, Boscardin WJ, Cenzer IS, Huang ES, Trumble KR, Eng C. The risks and benefits of implementing glycemic control guidelines in frail older adults with diabetes mellitus. Journal of the American Geriatrics Society. 2011;59:666-72.

11. Herz $M$, Sun B, Milicevic $Z$, Erickson $P$, Fövènyi J, Grzywa $M$, et al. Comparative efficacy of preprandial or postprandial Humalog Mix75/25 versus glyburide in patients 60 to 80 years of age with type 2 diabetes mellitus. Clin Ther. 2002;24:73-86.

12. Warren ML, Conway MJ, Klaff $\sqcup$, Rosenstock J, Allen E. Postprandial versus preprandial dosing of biphasic insulin aspart in elderly type 2 diabetes patients. Diabetes Res Clin Pract. 2004;66:23-9.

13. Kim DH, Sebastian S. Measuring frailty using claims data for pharmacoepidemiologic studies of mortality in older adults: evidence and recommendations. Pharmacoepidemiol Drug Saf. 2014;23:891-901.

14. Sourial N, Bergman H, Karunananthan S, Wolfson C, Payette H, GutierrezRobledo LM, et al. Implementing frailty into clinical practice: a cautionary tale. J Gerontol A Biol Sci Med Sci. 2013;68:1505-11.

15. Araki A, Ito H. Diabetes mellitus and geriatric syndromes. Geriatr Gerontol Int. 2009;9:105-14.

16. Brown AF, Mangione CM, Saliba D, Sarkisian CA; California Healthcare Foundation/American Geriatrics Society Panel on Improving Care for Elders with Diabetes. Guidelines for improving the care of the older person with diabetes mellitus. J Am Geriatr Soc. 2003;51(5 Suppl Guidelines):S265-80.

17. Gregg EW, Beckles GL, Williamson DF, Leveille SG, Langlois JA, Engelgau $\mathrm{MM}$, et al. Diabetes and physical disability among older U.S. adults. Diabetes Care. 2000;23:1272-7.

18. Amer MS, Farid TM, El-Rahman EEA, EL-Maleh DM, Omar OH, Mabrouk RA Ability of Comprehensive Geriatric Assessment to Detect Frailty. Advances in Aging Research. 2014;3:63-9.

19. Kim KS, Kim SK, Sung KM, Cho YW, Park SW. Management of type 2 diabetes mellitus in older adults. Diabetes Metab J. 2012;36:336-44.

20. Duckworth W, Abraira C, Moritz T, Reda D, Emanuele N, Reaven PD, et al. Glucose control and vascular complications in veterans with type 2 diabetes. N Engl J Med. 2009;360:129-39. 